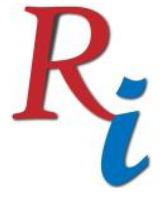

Asia Proceedings of Social Sciences

(APSS)

www.readersinsight.net/APSS

\title{
A PRILIMINARY STUDY FOR THE NEED OF DEVELOPING INTEGRATED STEM COURSE TRAINING MODULE \\ Usman Galadima*
}

Department of Science and Mathematics Education

Universiti Teknologi Malaysia, Johor Bahru

Malaysia

Department of Science Education

Sokoto State University, Sokoto

Nigeria

\section{Zaleha Ismail}

Department of Science and Mathematics Education, School of Education, Universiti Teknologi Malaysia, Johor Bahru,

Malaysia

\section{Norulhuda Ismail}

Department of Science and Mathematics Education, School of Education, Universiti Teknologi Malaysia, Johor Bahru,

Malaysia

*Corrosponding author's Email: usman.galadima@ssu.edu.ng

Author's Biography

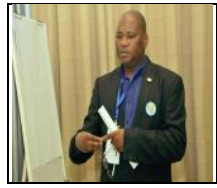

Usman Galadima is a native of Sokoto State, Nigeria. He obtained his Master and Bachelor Degrees in Mathematics Education from Usmanu Danfodiyo University, Sokoto, Nigeria. He is curently a PhD student in the School of Education, Universiti Teknologi Malysia (UTM). He is a lecturer in the Department of Science Education, Faculty of Education, Sokoto State University, Nigeria. He has research interest in pedagogical content knowledge in teaching iSTEM course, Mathematics Teacher Training and STEM literacy research.

Peer-review under responsibility of $3^{\text {rd }}$ Asia International Multidisciplanry Conference 2019 editorial board

(http://www.utm.my/asia/our-team/)

(C) 2019 Published by Readers Insight Publisher,

lat 306 Savoy Residencia, Block 3 F11/1,44000 Islamabad. Pakistan,

info@readersinsight.net

This is an open access article under the CC BY-NC-ND license (http://creativecommons.org/licenses/by-nc-nd/4.0/). 


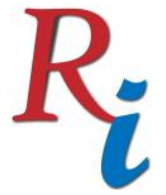

\section{Asia Proceedings of Social Sciences \\ (APSS) \\ www.readersinsight.net/APSS}

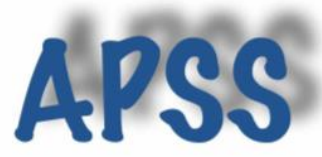

\section{Rese a r ch H i g h I igh t s}

This preliminary study is conducted as a preamble for the need to develop the iSTEM course training module for preparing the pre-service mathematics teachers' readiness in teaching the iSTEM course. Based on this preliminary study, the researchers were guided by the theory of constructivism learning and model of pedagogical content knowledge (PCK) in collecting the qualitative data for the need to develop iSTEM course training module using semi-structured interview questions. Thus, six university lecturers in Nigeria was purposefully choosing in conducting the preliminary interview in order to identify the need for iSTEM course training and module for teaching iSTEM course. The interview data collected by the researchers was inductively analysed using an exploratory content analysis strategy. The results of this study indicated that all the six interviewers' participants revealed that there is a need for the development of iSTEM course training module. This study suggests that iSTEM course training module should be integrated into the Nigerian educational curriculum for training the pre-service mathematics teachers' readiness in teaching iSTEM course. The five components of PCK

\section{Graphical Abstract}

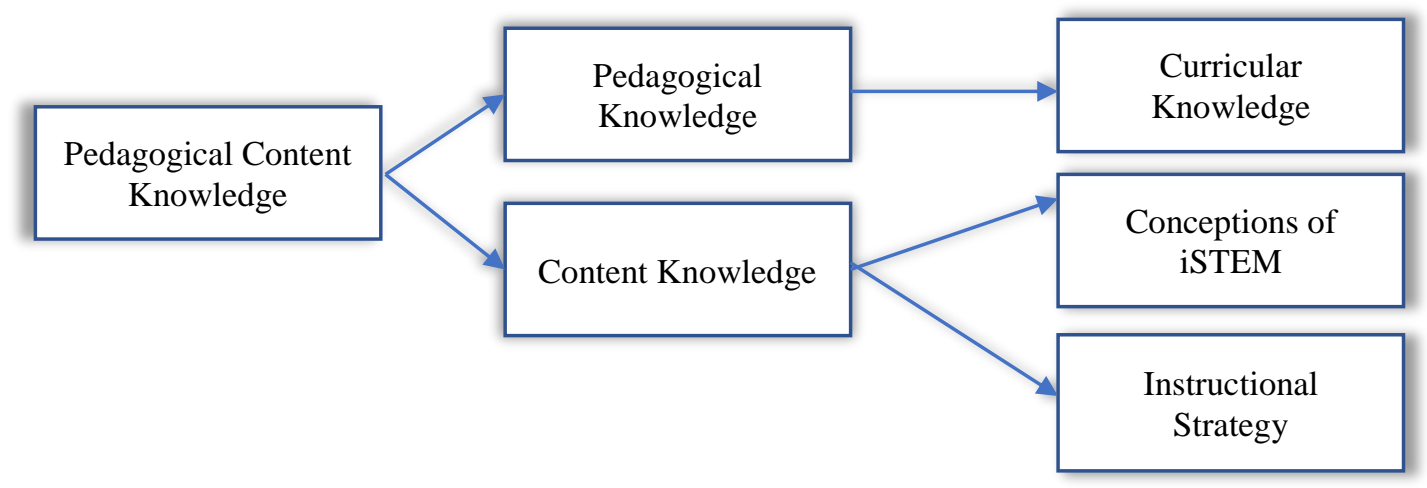

\section{Research Objectives}

The purpose of this research was to present a preliminary study on the need to develop the iSTEM course training module for preparing the pre-service mathematics teachers' readiness in teaching the iSTEM course in Nigeria. The study would centre on the following research questions:

1. What do you know about the concept of iSTEM?

2. Do you know how to train the learners to be prepared to teach the iSTEM course?

3. Are there any needs for the integrated STEM courses in making the teaching and learning more connected?

4. Do you think a training module is needed for teaching iSTEM course?

The ideal practice in the whole world is moving towards iSTEM education (Evans, 2015). But in Nigeria, each of the STEM discipline is taught separately without any connection between the fields (Okpala, 2012). The situation is that the pre-service teachers are not exposed to the iSTEM course (Okpala, 2012; Ugo, 2016). The consequences associated with this situation of single discipline pedagogy may not help the pre-service mathematics teachers to understand the connection within the STEM disciplines. As such, if the iSTEM education is not incorporated in the Nigerian educational system, it will affect the productivity of the learners. 


\section{Methodology}

This study uses a qualitative research design of data collection using semi-structured interview questions in order to explore the need to develop the iSTEM course training module for the pre-service mathematics teachers. The semi-structured interviews are used to give the respondents the opportunity to spell out their viewpoints on the phenomenon under study (Creswell, 2013). Purposive sampling was used in choosing 6 university lecturers in Nigeria for conducting this study to identify and seek their insights concerning the need for the iSTEM course training and module for teaching iSTEM course. The interviews data collected was tabulated based on the questionnaire items and analysed inductively (Thomas, 2006) using the content analysis approach (Mayring, 2015). According to Creswell (2013), an interview data produced can be transcribed and inductively categorised using qualitative content analysis techniques. The qualitative content analysis techniques was used in this study because it is one among the several qualitative methods employed to make meaning out of textual raw data into a summary format (Elo et al., 2014),

\section{Results}

The results of this preliminary study indicated that all the respondents $(100 \%)$ have no idea and knowledge about the concept of iSTEM. This finding is supported to the study of Okpala (2012), that the teachers in Nigeria are not exposed to integrated STEM and were only receiving training in the single and separate disciplines of STEM education. Also, they pointed out that they have inadequate knowledge in teaching iSTEM course. The interviews also revealed that the teachers were not exposed to the integration of different STEM disciplines as there are no teaching guides for iSTEM course provided in the National Universities commission (NUC) benchmark in Nigeria. Likewise, most respondents also stated that there are no iSTEM teaching and learning module available for the teaching of iSTEM provided by the NUC. Additionally, when they were asked about their preparedness for the teaching of iSTEM, 5(83.3\%) out of the 6 respondents feel unprepared to connect several STEM disciplines and 4(66.7\%) out of the 6 participants also mentioned that had insufficient knowledge for teaching the iSTEM course. The results of this preliminary study conducted supported the need for the iSTEM course training and the development of iSTEM course module.

\section{Findings}

The findings of this preliminary study were based on the five key components of pedagogical content knowledge needs recorded during the interviews with respects to the conception of iSTEM, the pedagogical knowledge, content knowledge, curricula knowledge, instructional strategy for teaching iSTEM course. Categorically, all the respondents expressed a need for a training module for teaching iSTEM course in making the teaching and learning more connected. Thus, the outcomes of this preliminary study provided a strong justification for the researchers of this study to design and develop iSTEM training module as a guideline for the pre-service mathematics teachers to be prepared for the teaching of an iSTEM course. Consequently, all of the respondents recommended the need for teaching the iSTEM course and to be incorporated into the Nigerian educational system. In addition, this finding is in line with the study of Ugo (2016), that call for action to integrate STEM disciplines into the Nigerian curriculum. 


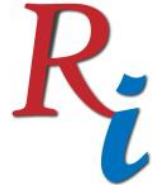

\section{Asia Proceedings of Social Sciences \\ (APSS) \\ www.readersinsight.net/APSS}

\section{References}

Creswell, J. W. (2013). Research design: Qualitative, quantitative, and mixed methods approaches. Far East Square, Singapore: Sage publications Asia-Pacific Pte Ltd.

Elo, S., Kääriäinen, M., Kanste, O., Pölkki, T., Utriainen, K., \& Kyngäs, H. (2014). Qualitative content analysis: A focus on trustworthiness. SAGE open, 4(1), 1-10. doi:101177/2158244014522633

Mayring, P. (2015). Qualitative content analysis: Theoretical background and procedures. In Approaches to qualitative research in mathematics education: pp. 365-380 Klagenfurt, Austria.

Okpala, P. N. (2012). Reforms in Science, Technology, Engineering and Mathematics (STEM) Education. Paper presented at the Keynote Address 54th Science Teachers Association of Nigeria (STAN).

Thomas, D. R. (2006). A general inductive approach for analyzing qualitative evaluation data. American journal of evaluation, 27(2), 237-246.

Ugo, E. A., Akpoghol T.V. (2016). Improving Science, Technology, Engineering and Mathematics (STEM) Programs in Secondary Schools in Benue State Nigeria: Challenges and Prospects. Asia Pacific Journal of Education, Arts and Sciences, 3(3), 6-16. 